\title{
Research into Doctoral Education: A Survey of Institutional Research Projects in Southern Africa
}

\author{
Eli Bitzer
}

\section{Introduction}

The title of this book indicates an exploration of intersecting contexts and practices of institutional research (IR) in South African higher education. Amongst the many definitions of the concept of IR worldwide (Chirikov 2013; Shreeve 2010), the term is often described as exploring, understanding and explaining the institution for the institution, but also as having a broader function (Webber \& Calderon 2015:10-11). As this volume highlights different dimensions of IR related to higher education issues, contexts and practices in South Africa, this chapter focuses on IR and doctoral education.

I address here three objectives. Firstly, the question of what constitutes a doctoral degree or 'doctorateness' in order to provide some background to doctoral education as an object of investigation. Since the interrelated sets of factors that influence doctoral education are also important, I emphasise the contextual, administrative and academic factors related to doctoral education. Secondly, I probe international research related to doctoral education in order to provide a backdrop to the role of IR in Southern Africa; and thirdly, I report on the results of a limited survey on doctoral education in Southern African and suggest possible future roles for IR and agendas for doctoral education.

The term 'doctoral education' in this chapter is understood in its broadest sense, referring to the international, national, institutional and individual efforts to produce doctoral qualifications. 'Doctoral education' is thus not confined to, but may include, research education, of which the aim is to assist doctoral candidates in various ways and at various stages to graduate successfully (Cloete, Mouton and Sheppard 2015). Although some information on IR on doctoral education for this chapter was readily available from a number of South African universities, it was more challenging to generate information on projects from other Southern African universities.

\section{Doctoral education and 'doctorateness'}

For those who research doctoral education, the doctoral degree as a research object has always been a complex, dynamic and evolving phenomenon. Its evolution spans the period from early medieval times when the doctorate was a 'license to teach', to its German Humboldtian conception as a research degree, to a range of modern variations (Simpson 1983; Taylor and Beasley 2005). Doctoral education differs internationally (Green and 
Powell 2005; Powell and Green 2007) with variations across space, time and disciplines. The doctorate is thus characterised by diversity (Neumann 2003, 2007; Usher 2002; Park 2005 ; 2007) with several variants in use - from professional and practice-based doctorates to doctorates by publication (United Kingdom Council for Graduate Education 2002; Frick 2015). Recently, the history of the development of the doctorate in South Africa has also attracted attention (Herman 2015).

Doctoral variety foregrounds the notion of 'doctorateness' put forward by Trafford and Leshem $(2009 ;$ 2011). For them, doctorateness is principally a feature of a final research product, which may be expressed in a doctoral thesis or a collection of publishable or published work. This "product view" of the doctorate is, however, hotly debated (Wellington 2013; Poole 2014). Trafford and Leshem (2011:38-52) identified 12 basic components that often constitute a doctorate. Figure 1 shows these components in a coherent view of what is expected from a candidate who wants to attain a doctorate. Doctoral examiners have to exercise judgement in deciding whether or not (or to what extent) each of these 'outcomes' of doctoral education is displayed. Exactly what, how large or how small a 'contribution to knowledge' should be or what precisely constitutes 'engagement with theory' are difficult questions to answer. Trafford and Leshem argue that doctorateness is demonstrated when a synergy between all the 12 components of doctoral studies are achieved (2011:52). Final answers and judgements may vary considerably across disciplines, institutions, countries and doctoral examiners.

\begin{tabular}{|c|c|c|c|}
\hline $\begin{array}{c}\text { Contribution } \\
\text { to knowledge }\end{array}$ & $\begin{array}{c}\text { Stated gap } \\
\text { in knowledge }\end{array}$ & $\begin{array}{r}\text { Explicit } \\
\text { research } \\
\text { questions }\end{array}$ & $\begin{array}{c}\text { Conceptual } \\
\text { framework }\end{array}$ \\
\hline $\begin{array}{c}\text { Conceptual } \\
\text { conclusions }\end{array}$ & \multicolumn{2}{|c|}{ SYNERGY } \\
AND & $\begin{array}{c}\text { Explicit } \\
\text { research } \\
\text { design }\end{array}$ \\
\cline { 3 - 4 } $\begin{array}{c}\text { Research } \\
\text { questions } \\
\text { answered }\end{array}$ & \multicolumn{2}{|c|}{ DOCTORATENESS } & $\begin{array}{c}\text { Appropriate } \\
\text { methodology }\end{array}$ \\
\hline $\begin{array}{c}\text { Coherent } \\
\text { argument }\end{array}$ & $\begin{array}{c}\text { Engagement } \\
\text { with theory }\end{array}$ & $\begin{array}{c}\text { Clear/concise } \\
\text { presentation }\end{array}$ & $\begin{array}{c}\text { 'Correct' } \\
\text { fieldwork }\end{array}$ \\
\hline
\end{tabular}

Figure 1: Scholarly components of the doctorate

Adapted from Trafford and Leshem, 2011:38

If it is accepted that IR is about exploring, understanding and explaining the institution for the institution in a broad and comprehensive sense (Webber \& Calderon 2015), it is equally important for IR practitioners to view doctoral studies as much more than the number of postgraduate enrolments, throughput figures and the amount of subsidy generated.

\section{Factors influencing doctoral provision and education}

Research on doctoral education has to attend to various interlinking factors that influence the nature, completion and quality of doctorates. As Figure 2 below suggests, at least three sets of factors impact on doctoral studies, namely contextual, administrative and academic factors. 


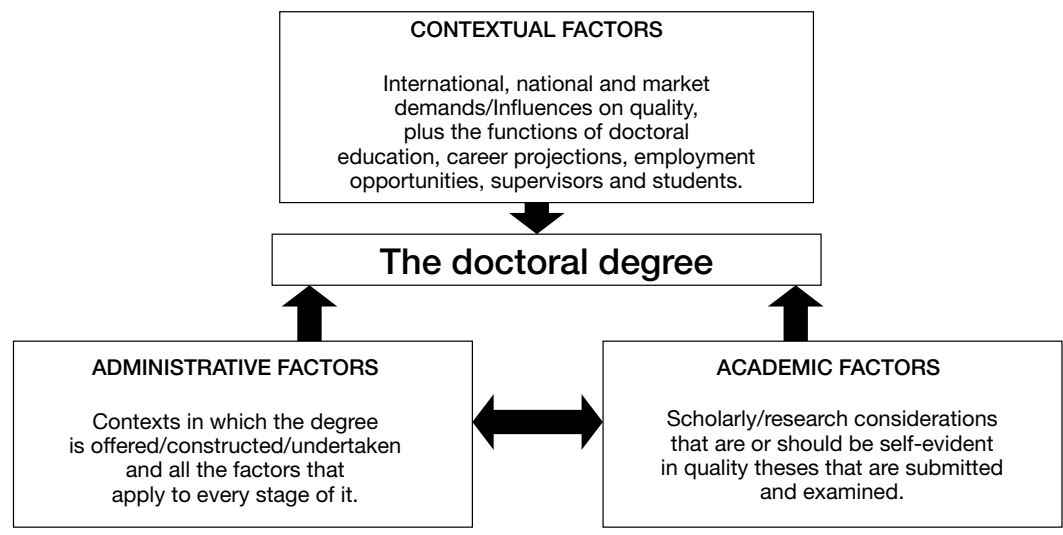

Figure 2: Factors influencing the doctorate

Based on Trafford, 2012

\section{Contextual factors}

The contexts in which doctoral education is offered and conducted (Trafford 2012) are of major importance. Examples of different contexts include international, regional and national demands for doctorates, the quality and reputation of doctoral degrees, the functions of the doctorate, career prospects of graduates, the institutional position of candidates and supervisors. Several studies indicate that doctoral education is not solely an academic or professional concern (Boote and Beile 2005; Bansel 2011; Acker and Hague 2015). For instance, in some disciplines or areas of study, doctoral graduates are over-represented, while in others there is underproduction (Mowbray and Halse, 2010; Malfroy 2011; Neumann and Tan 2011). Overproduction or underproduction at the systemic or institutional level also ties in with the reality that doctoral quality varies across institutions, countries and disciplines (Schömburg and Teichler 2006; Wildly, Peden and Chan 2015). In South Africa, for instance, doctorates from particular institutions or fields of study are in high demand, while the quality of others is often met with suspicion (Mouton 2007; 2015). This is also true when doctorates in some disciplines are compared internationally (Cross and Backhouse 2014; Mouton 2015).

The issue of systemic and institutional transformation is a particular concern worldwide and in South Africa in particular. Prinsloo (2014) has emphasised that currently less than $15 \%$ of university professors in South Africa are black (also see Van der Merwe, 2014), and the vast majority of researchers in higher education are white and male (Habib, Price and Mabelebele, 2014). Grove 2013 (in Prinsloo 2014) also reports that a United Kingdom survey in 2013 survey found that only one in every five professors in the UK is female while $45 \%$ of non-professorial academics are female. According to Mason (2011) not only are there fewer women at the top of the academic hierarchy in universities in the United States, but they are also paid less than their male colleagues. Mason found that only $23 \%$ of the professoriate in the United States of America is female and Brown (2013) reports that male academics in the USA have a four-to-one chance of being interviewed for a position compared to female scholars in the same field. 
The ageing professoriate is another important contextual factor. At the University of South Africa (UNISA), for instance, academics younger than 40 years of age produced only $20 \%$ of research outputs in 2011, while about half of the institution's research outputs was produced by academics older than 50 (Prinsloo 2014). Out of a total of 504 associate and full professors, only $40 \%$ (204) is female and among the 144 black associate and full professors, only $27 \%$ (39) is female.

Worldwide, the professoriate is increasingly under pressure to do more with less, while being blamed, amongst other things, for an ever-expanding list of shortcomings of the university (Altbach and Finkelstein 2014). Not only are salaries lagging behind in terms of the cost of living, but there is increasing evidence that the middle-class existence of professors is something of the past and many professors in many parts of the world are now moonlighting to make ends meet (Saccaro in Prinsloo 2014). Higher education has been increasingly squeezed by government policies and changing funding agreements, while increasing managerialist management practices raise concerns that institutions are often more interested in performance measures than with their quality (Tight 2012).

In the North American context, only 200 out of a total of 4,500 universities are research universities, making positions for research professors scarce (Altbach and Finkelstein 2014). In the light of increasing constraints on funding, however, researchers are evaluated with regard to the amount of funding they obtain for their research. Currently many researchers have to pay their own salaries through external funding. Professorships, as tenured or fulltime academic posts, are also becoming increasingly disposable features of neoliberal higher education (Altbach and Finkelstein 2014) as the number of appointments of adjunct academic and full-time administrative staff members exceed the appointment of academics. In 2012, of the 1.5 million professors in the USA, 1 million were adjunct professors appointed on a contract basis (Scott 2012).

The contexts in which doctoral candidates and supervisors work are also increasingly under the spotlight. Power relations, the apprenticeship model of supervision, access to communities of research, the question of cultural capital and who exerts agency, are some of the contextual issues begging for further exploration (also see Maton 2012 and Bordieu 1977).

Against the background of these few examples, there is agreement that doctoral education is important in supporting and promoting the research capacity and reputation of universities (Austin and McDaniels 2006; Cloete et al. 2015). This may, in turn, contribute to research products that directly or indirectly influence scientific, economic or entrepreneurial activities (Fox 2001; Green and Powell 2005; Fillery-Davis 2014). The stature of developing countries such as South Africa is often measured in terms of the capacity to contribute to knowledge - largely pointing to the quality of doctoral education and provision (Cloete et al. 2015).

\section{Administrative factors}

All universities granting doctorates have rules and regulations regarding doctoral education. There are general and also specific requirements related to faculties, schools, colleges, disciplines and departments. Most of these regulations relate to procedures for doctoral 
applications, admissions, submission of research proposals, measures concerning research integrity, supervision, thesis submission, examination and graduation as set by administrators, graduate offices and academic units.

It is relatively easy to check whether such rules and regulations are adhered to, but determining the need for these measures and the contribution of such measures to the quality of the doctorates is more complicated. For instance, what are the institutional quality measures that prevail for research proposals, what constitutes quality supervision processes and what is a quality doctoral examining process? A s doctoral education does not involve fixed curricula, its quality has to be assured by individual, disciplinary or methodology experts and peers. As Emilsson and Johnsson (2007) and Holbrook et al. (2014) have, however, asked: Who checks the checkers? And is such 'checking' at all possible by any other means than by directly monitoring doctoral products and outputs?

The question thus arises whether and how IR could contribute to promoting the effectiveness and efficiency of requirements towards doctoral outcomes and products. Preliminary findings from a recent study into quality measures in one discipline across six universities (Du Preez and Simmonds 2015) indicate that such measures at the doctoral level may not only be inadequate, but also applied inconsistently. Their study shows how current quality measures could either be simplified, streamlined and better coordinated to promote doctoral education curricula.

\section{Academic factors}

On the surface, it may seem that IR has little to contribute to an improved understanding of the academic factors that govern doctoral education. There are many examples, however, where IR has made meaningful contributions to the scrutiny of institutional measures to promote doctoral quality. To name two such examples, a cross-institutional study into the concluding chapters of doctoral theses in one discipline at five universities was conducted by Trafford, Leshem and Bitzer (2013). The researchers investigated whether such chapters explicitly state the knowledge contribution of the study. Surprisingly, almost half of the 100 doctoral theses analysed (20 from each institution) did not indicate a unique knowledge contribution in their concluding chapters. These findings indicate that either the supervisors or the doctoral students have not adhered to their own institutional stipulations, that examiners did not properly check for such requirements or that the knowledge contribution was stated elsewhere in the thesis. The second example is the study of Slabbert-Redpath (2015) in which he investigated the quality of examiners' reports in one discipline at six South African universities. The examination reports of approximately 150 successfully completed doctoral studies were compared for adherence to the institutional examination criteria. The study also compared examination reports for length, depth of assessment and recommendations for the improvement of studies prior to graduation. Preliminary findings indicate inconsistencies across examination reports and institutions. In many cases examination reports fail to meet basic requirements, and yet candidates have passed their examinations in spite of inadequacies related to examination procedures and reports. The study points to substantial variations in the quality of doctoral examinations which, in turn, generate questions about doctoral examination criteria and the comparability of doctoral qualifications within and across institutions. 
Purists may legitimately ask whether such examples of research into doctoral quality qualify as institutional research or merely as research into higher education. In my view, there are many overlaps and areas for further development here, even pointing to a need for improved coordination and synergy between higher education researchers and IR practitioners. The next section will thus shift the focus to international research on doctoral education as the backdrop to a survey on IR-related projects on doctoral education. The approach followed was to indicate research clustering around particular research themes, except for research on doctoral education in Southern and South Africa, which will be treated separately.

\section{International Research on the Doctorate}

A review of international literature on the last 12 years of research on doctoral education reveals at least eleven prominent themes. Most of these are related, but for the purpose of this chapter each theme will be discussed briefly and separately.

\section{Doctoral programmes and doctoral genres}

One extensive piece of research that has pointed to the need for new doctoral education options is the Carnegie-sponsored study by Walker et al. (2008) titled The formation of scholars - Rethinking doctoral education for the twenty-first century. Many other studies also point to the need for new options and genres of the doctorate (Hathaway, Nagda and Gregman 2002; Boud and Tennant 2006; Lee, Brennan and Green 2009). While some studies argue that doctoral education needs to promote intellectual virtues (Mowbray and Halse 2010), others (Wellington 2013; Poole 2014) argue respectively for and against the idea that a doctorate must have a discernable "inner sense", i.e. the notion of "doctorateness" as propagated by Trafford and Lesham (2009). Still others see doctoral education as offering a wide range of options and following a progressive trajectory from research dependence to independence (Willison \& O'Regan 2007; Salter 2013), while in studies related to doctoral genres (Filery-Davis 2014; Wildly, Peden \& Chan 2015), professional doctorates took prominence - implying closer attention to the research needs of professions, business and industry.

\section{Preparing future academics}

A prominent theme in literature on doctoral education relates to how current academics should, in time, be replaced with new, upcoming and promising graduates. Researchers have emphasised the promotion of scholarship (Boote and Beile 2005), the socialisation of academics into higher education (Austin and McDaniels 2006), how the selection of academics is constituted and regulated (Bansel, 2011) and how doctorate education presents professional learning opportunities (Cantwell et al. 2015). Most thematic studies point to the need to identify and educate future academics to capacitate universities for promoting excellent teaching and research worldwide. Cloete et al. (2015), however, argue that the purpose of the doctorate is much broader than the training of future academics and should also include the identification of talent for participation in a knowledge economy. 


\section{Time to degree}

In doctoral education, the time to graduation points, amongst other things, to the effective and efficient use of resources and to the quality of doctorates. Previous research has focused on predicting doctoral success (Wallingham 1974), but more recently, such studies have turned to factors influencing the time to degree (Ferrer de Valero 2001; McAlpine and Norton 2006; Kearns, Gardiner and Marshall 2008), trends in doctoral attrition (Golde 2005), different forms of doctoral support to doctoral candidates (Carter 2011; Mewburn 2011; Pillbeam Lloyd-Jones and Denyer 2013) and determinants of the time to degree (Van der Haert et al. 2014). While demographic differences such as gender and ethnicity are well accounted for in time-to-graduate studies, few studies have inquired into the differences between full-time and part-time doctoral candidates. The latter probably relates to the fact that many national and institutional information systems on the doctorate do not capture such data.

\section{Candidates' experiences of doctoral studies}

Doctoral candidates are often requested to reflect on their experiences of doctoral studies, and consequently research in this area has multiplied. This includes studies investigating the motivations and expectations of doctoral candidates (Golde and Dore 2001) and the experiences of candidates as co-publishers (Hopwood, 2010). The studies also examine how work in PhD projects is seen as important research (Stubb, Pyhalto and Lonka 2014) and how mismatches between the expectations and experiences of doctoral supervisors and candidates influence studies (Holbrook et al. 2014; Cantwell et al. 2015). Increasingly, studies have also focused on the study experiences of doctoral candidates, which has proved to be helpful to supervisors (McAlpine, Jazvac-Martek and Hopwood, 2009; Bitzer and van den Bergh 2014).

\section{Doctoral supervision}

Since the publication of a ground-breaking article on professional learning for supervisors (Pearson and Brew 2002), other relevant topics include doctoral supervision as a special pedagogy (Emilsson and Johnsson 2007; Halse 2001a; McCallin and Nayar 2011; Kiley 2011; Erichsen, Bologer and Halupa, 2014), an understanding of doctoral education as a threshold concept (Lee 2008; Trafford \& Leshem 2008; Linden, Ohlin and Brodin 2014) and connections among institutions, knowledge areas and supervisory relationships (Adkins 2009; Maxwell and Smyth 2011). Doctoral education as a threshold concept is of particular concern, since, as long as doctoral candidates and supervisors do not clearly understand what a doctorate means and represents, its supervision will remain inadequate. To address such issues, international conferences on doctoral supervision and doctoral education are regular events, including the biennial Quality in Postgraduate Research (QPR) conference in Adelaide, Australia and the series of biennial Postgraduate Supervision (PGS) conferences in Stellenbosch, South Africa.

\section{Impact of the doctorate}

A growing area of research on doctoral education is into the ways in which doctoral studies impact on candidates' preparedness for scholarly work, on universities' research 
productivity, and on research in applied contexts such as industries and on society at large. Some researchers have argued for increased nuances in the way we consider the impact of doctoral education on different levels of knowledge production (Halse and Mowbray 2011). Others have explored the impact of joint university-industry research on doctoral education (Malfroy 2011) and the role of doctoral education as contributing to the formation of active researchers (Sinclair, Barnacle and Cuthbert 2014).

\section{Examining the doctorate}

Extensive national projects on doctoral examination by Holbrook, Bourke and others in Australia and the work of Lovitts in the USA on examining within disciplines have been widely referenced. Lovitts' $(2005 ; 2008)$ work on doctoral examination frameworks and related criteria applies to a range of disciplines, while national studies in Australia (Lovat, Holbrook and Bourke 2013; Holbrook et al. 2014; Holbrook, Bourke and Fairbairn 2015; Starfield et al. 2015) have dealt with large examination data sets. Starfield et al. (2015) have explained why and how examiners differ in their judgement of doctoral work, why particular theses get less favourable recommendations from examiners, why the quality of examiner feedback in examination reports varies and how better to understand the language of examination.

\section{Women in doctoral studies}

The status of women in graduate education and scientific careers has been studied extensively. Fox (2001) and Hirshfield and Joseph (2012), for example, have looked into a wide variety of aspects regarding gender - especially how to provide women with equal opportunities as doctoral candidates and scientists. Typical studies have included inquiries into gender specific doctoral education experiences (Carter, Blumenstein and Cook 2013), emotion in doctoral supervision and candidature (Cotterall 2013; Aitcheson and Mowbray 2014) and attracting women into intellectual communities (Walker et al. 2008:123).

\section{Student diversity in doctoral education}

In their recent study on doctoral student diversity, Pearson et al. (2011) claim that doctoral candidates, more than ever, bring different goals, expectations, career histories and responsibilities into doctoral education. Other cross-institutional studies (Crede and Borrego 2014) report that at least five constructs account for differences in doctoral studies, namely expectations, individual preference, perception of value, project ownership and study climate. In many cases, institutions find it challenging to deal with diversity issues related to doctoral education (Acker and Hague 2015).

\section{Doctoral success and graduates' career paths}

Until recently, a doctoral degree in a sought-after field could secure a graduate a good job, but increasingly the value of a doctorate has become an open question - even for graduates in science, engineering, technology and mathematics. Many inquiries have questioned the relationship between doctoral graduation and career prospects. Neumann and Tan (2011), for instance, have studied graduates' employment destinations as accounted for 
by disciplinary and institutional variations and by comparing trends in Australia to graduate employment in the USA and Europe, based on the studies of Schömburg and Teichler (2006). Other studies (Canal-Dominguez 2014) have inquired into factors that determine professional earnings as an objective measure of doctoral success, indicating uncertainty as to whether a doctoral degree will actually pay off. If the degree is, however, obtained in the right field and graduates are open to more than one career path, it may minimise the risk of being jobless.

\section{Doctoral writing}

Aitcheson (2015) conducted studies on how the writing lives of doctoral candidates and graduates have changed over time. Doctoral students across all disciplines are likely to publish or are pressured to publish. They are thus expected to show mastery of an increasing range of research genres, which, in turn, drive new ways of publishing, even during their doctoral education. At the same time, however, research into writing and publishing for doctoral candidates creates more opportunities to investigate which writing strategies work best for whom, how research into doctoral writing connects and how to share experiences contributing to the quality of doctoral writing (Kamler and Thomson 2014).

Having provided a brief overview of the prominent themes in research on doctoral education, I will elaborate in the next section on relevant research projects focused on doctoral education - particularly in studies related to Southern and South Africa.

\section{Institutional Research on Doctoral Education}

Cloete and Mouton (2015) list several important studies on doctoral education that have been published in South Africa. These include the study commissioned by the Council on Higher Education (CHE) on the statistical profile of postgraduate studies (2009), the report by the Academy of Science in South Africa (ASSAf) on the state of the doctorate (ASSAf 2010), a study by (the then) Higher Education South Africa (HESA) on a national programme to develop the next generation of academics for South Africa (HESA 2011) and studies by the Centre for Higher Education Trust (CHET) focusing on the discourses and dynamics of the doctorate and on data.

All these studies have contributed in important ways to a better understanding of the position, issues and challenges facing doctoral education in South(ern) Africa, including the need for increasing doctoral throughput and output (especially in particular disciplines and fields of study), ways to prevent and decrease doctoral dropout and discontinuation, strengthening the doctoral pipeline, providing financial support to doctoral candidates, strengthening doctoral supervision and achieving equity and quality in doctoral enrolments and output. Without elaborating on these studies, one may acknowledge their importance and relevance to IR at South African universities.

Studies on doctoral education are limited in Southern Africa, (here understood as the countries of the Southern African Development Community (SADC), excluding South Africa). Studies by the Southern African Regional Universities Association (SARUA) (Kotecha, 2012) as well as a study led by the European University Association (EUA) (Jørgensen 2012) 
which compared doctoral education provision in Africa, Asia, Latin America and Europe, should be mentioned. The latter study included useful information on doctoral education in Southern Africa for 66 universities from 15 countries, and highlighted challenges related to infrastructure, funding, administrative reform, research investment and student retention.

The overview of international, regional and national literature on research into doctoral education provided some background for conducting a small-scale survey amongst IR practitioners in Southern Africa. The aim was to determine the nature and extent of IR projects on doctoral education between 2011 and 2015. This is discussed in the next section.

\section{A survey of institutional research on doctoral education}

In April 2015 I conducted an e-mail survey amongst institutional researchers and institutional representatives affiliated to the Southern African Association for Institutional Research (SAAIR) posing the following question to them, If applicable, what institutional research projects related to doctoral education were conducted at your university during the past five years? It was explicitly stated that such projects should exclude the annual reporting, for instance (in South Africa), in terms of the Higher Education Management Information System (HEMIS) and the Research Information Management System (RIMS), but include institutional research projects or studies commissioned by their universities. I wanted to gather information on research projects on doctoral education in their institutions that is of institutional concern, including, but not restricted to, any studies conducted by IR units. Non-university members of SAAIR and non-SAAIR researchers were excluded from the survey.

Representatives of 18 of 23 South African universities and three of nine other Southern African universities responded. Of the 18 South African universities, nine representatives reported that significant IR projects related to doctoral education were conducted in the previous five years. Of the non-South African group, two members reported that they were not aware of any IR on doctoral education, while one reported quite extensively on his awareness of such research. The information is reflected in Tables 1 and 2.

Table 1: IR on doctoral education reported by South African SAAIR members

\begin{tabular}{|l|l|l|l|}
\hline \multicolumn{1}{|c|}{ Institution } & \multicolumn{1}{c|}{ Year } & \multicolumn{1}{c|}{ Nature of topic } & \multicolumn{1}{c|}{ Dissemination } \\
\hline $\begin{array}{l}\text { University A } \\
\text { (traditional } \\
\text { university) }\end{array}$ & 2014 & $\begin{array}{l}\text { Doctoral throughput rates were } \\
\text { specifically monitored in a longitudinal } \\
\text { fashion and reasons for the apparent } \\
\text { internal inefficiency of doctoral education } \\
\text { were closely studied. }\end{array}$ & $\begin{array}{l}\text { This represents an institution-wide study which } \\
\text { includes both continuing and former students } \\
\text { as well as those who had discontinued their } \\
\text { studies. The report was shared with all deans } \\
\text { and discussions have taken place in faculty } \\
\text { boards. Findings are being implemented to } \\
\text { enhance postgraduate education success. The } \\
\text { report is confidential. }\end{array}$ \\
\hline
\end{tabular}


Botha J \& Muller N (eds) 2016. Institutional Research in South African Higher Education. Stellenbosch: SUN PRESS

Research into Doctoral Education

\begin{tabular}{|c|c|c|c|}
\hline Institution & Year & Nature of topic & Dissemination \\
\hline $\begin{array}{l}\text { University B } \\
\text { (comprehensive } \\
\text { university) }\end{array}$ & 2014 & $\begin{array}{l}\text { Intercultural supervision; } \\
\text { Plagiarism in doctoral studies. }\end{array}$ & $\begin{array}{l}\text { The project was conducted in one faculty, but } \\
\text { shared with supervisors institutionally. It was } \\
\text { disseminated as a conference paper at an } \\
\text { education conference in } 2014 \text {. } \\
\text { The study was also done in one faculty and } \\
\text { disseminated to relevant institutional bodies. } \\
\text { Results were presented at a conference on } \\
\text { postgraduate supervision is being prepared as } \\
\text { a book chapter. }\end{array}$ \\
\hline $\begin{array}{l}\text { University C } \\
\text { (university of } \\
\text { technology }\end{array}$ & 2013 & $\begin{array}{l}\text { How doctoral students deal with } \\
\text { supervisors' feedback. }\end{array}$ & $\begin{array}{l}\text { This study was conducted in one faculty, but } \\
\text { institutionally disseminated. It was presented as } \\
\text { a paper at an educational conference in } 2013 .\end{array}$ \\
\hline $\begin{array}{l}\text { University D } \\
\text { (traditional } \\
\text { university) }\end{array}$ & 2014 & Equity of access to doctoral studies. & $\begin{array}{l}\text { The study was conducted by the Postgraduate } \\
\text { School and disseminated institutionally. The } \\
\text { project report is confidential. }\end{array}$ \\
\hline $\begin{array}{l}\text { University E } \\
\text { (traditional } \\
\text { university) }\end{array}$ & $\begin{array}{l}\text { On- } \\
\text { going }\end{array}$ & $\begin{array}{l}\text { Longitudinal research into several years } \\
\text { of specific data of student progression at } \\
\text { the doctoral level. }\end{array}$ & $\begin{array}{l}\text { The study was conducted by the Institutional } \\
\text { Research Unit and disseminated institutionally. } \\
\text { The report is confidential. }\end{array}$ \\
\hline $\begin{array}{l}\text { University F } \\
\text { (traditional } \\
\text { university) }\end{array}$ & 2014 & $\begin{array}{l}\text { The Directorates of Institutional Research } \\
\text { and Institutional Analysis have devised } \\
\text { a research platform to monitor Master's } \\
\text { and doctoral production since } 2004 \text {. } \\
\text { This has enabled various cohort analyses } \\
\text { of the institution's doctoral constituency; } \\
\text { Market research has been undertaken } \\
\text { via a number of student satisfaction } \\
\text { surveys on doctoral experiences. } \\
\text { Various internal research papers on } \\
\text { doctoral pedagogies are also part of the } \\
\text { repertoire. }\end{array}$ & $\begin{array}{l}\text { The study was conducted by the College of } \\
\text { Graduate Studies, but is ongoing and attends } \\
\text { to different doctoral education matters. } \\
\text { The findings have served at the Senate } \\
\text { Research, Innovation and Higher Degrees } \\
\text { Committee as a means of developing more } \\
\text { sophisticated research policies, improving } \\
\text { doctoral performance and innovating different } \\
\text { models of doctoral supervision. The reports } \\
\text { are confidential. } \\
\text { These have been integrated into the } \\
\text { organisational architecture of the university's } \\
\text { strategic plan. }\end{array}$ \\
\hline $\begin{array}{l}\text { University G } \\
\text { (traditional } \\
\text { university) }\end{array}$ & 2014 & $\begin{array}{l}\text { Small research projects into doctoral } \\
\text { education within the field of higher } \\
\text { education studies have been undertaken } \\
\text { by individual researchers. Examples: } \\
\text { Genres of the doctorate, the role of } \\
\text { scholarly communities in doctoral } \\
\text { education and the challenges related to } \\
\text { doctoral writing. }\end{array}$ & $\begin{array}{l}\text { Disseminated through papers at conferences } \\
\text { and articles, some of which are currently under } \\
\text { review. The researchers are not part of the } \\
\text { Institutional Research Division. }\end{array}$ \\
\hline $\begin{array}{l}\text { University H } \\
\text { (traditional } \\
\text { university) }\end{array}$ & $\begin{array}{l}\text { On- } \\
\text { going }\end{array}$ & $\begin{array}{l}\text { Several projects have been undertaken, } \\
\text { including longitudinal tracking studies } \\
\text { of master's and doctoral students, the } \\
\text { development of new information systems } \\
\text { for studies at the postgraduate level, how } \\
\text { the PhD prepares new academics for } \\
\text { their careers and a comparative study of } \\
\text { the PhD by publication across faculties in } \\
\text { the institution. }\end{array}$ & $\begin{array}{l}\text { Some of these reports have been institutionally } \\
\text { published as helpful data to academic } \\
\text { managers, others are in progress and still } \\
\text { others are conducted in partnership with other } \\
\text { universities, both in South Africa and abroad. } \\
\text { Some of the researchers are not part of the } \\
\text { Institutional Research Division. }\end{array}$ \\
\hline $\begin{array}{l}\text { University I } \\
\text { (traditional } \\
\text { university) }\end{array}$ & 2014 & $\begin{array}{l}\text { Quality of postgraduate degrees and } \\
\text { doctoral degrees in particular. }\end{array}$ & $\begin{array}{l}\text { The results of the project were disseminated } \\
\text { to the Higher Degrees Committee, but little } \\
\text { action has apparently been taken on its } \\
\text { recommendations. The report is confidential. }\end{array}$ \\
\hline
\end{tabular}


(* In South Africa universities are classified as 'traditional' if offering a broad range of general formative and professional programmes at both undergraduate and postgraduate levels; as 'universities of technology' if offering a range of programmes that are vocationally and/or professionally oriented, and as 'comprehensive universities' if the offer the full spectrum of programmes, including vocational, professional and general formative programmes at both undergraduate and postgraduate levels)

Table 2: IR on doctoral education reported by SAAIR members in countries other than South Africa**

\begin{tabular}{|l|l|l|l|}
\hline \multicolumn{1}{|c|}{ Institution } & \multicolumn{1}{|c|}{ Year } & \multicolumn{1}{c|}{ Nature of topic } & \multicolumn{1}{c|}{ Dissemination } \\
\hline University X & 2014 & $\begin{array}{l}\text { Apart from South African institutions, } \\
\text { this university seems to be the only } \\
\text { other Southern African country that } \\
\text { keeps good African higher education } \\
\text { institution that reports doctoral statistics } \\
\text { to its Tertiary Education Commission } \\
\text { (TEC). This information is reflected in the } \\
\text { 2014 TEC report and was attached in } \\
\text { its response. The numbers of doctoral } \\
\text { graduates are, however, low and } \\
\text { worrying. }\end{array}$ & $\begin{array}{l}\text { Some African research on doctoral education } \\
\text { is reflected in a 2010 project report of the } \\
\text { International Association of Universities (IAU), } \\
\text { Innovative Approaches to Doctoral Education } \\
\text { in Africa' (IDEA). This report covers sub- } \\
\text { Saharan African countries generally and not } \\
\text { SADC countries. } \\
\text { The respondent mentioned that there is still a } \\
\text { lot of work to be done in gathering information } \\
\text { on doctoral education in Africa, and Southern } \\
\text { Africa in particular. That can only be possible } \\
\text { if the countries themselves and institutions put } \\
\text { in place appropriate mechanisms to collect } \\
\text { national and institutional data - currently few } \\
\text { have this capacity. }\end{array}$ \\
& & \\
\hline
\end{tabular}

(** The representatives of three institutions responded, but only one reported IR related work at the doctoral level)

The data generated from the nine institutions reflected in Table 1 revealed a limited but interesting picture. Firstly, as expected, most of the institutional research projects were conducted at traditional universities. Doctoral education obviously plays an important part in institutions with a stronger research focus and one would expect encouragement of institutional inquiry into this topic. At both the comprehensive university and university of technology (UOT) the reported IR projects were initiated and conducted within faculties or schools and then shared with the rest of the institution. The data thus show that at traditional and research-intensive universities the chances of initiating IR on doctoral education appear to be higher than at other institutions. This was also evident in that few comprehensives and UoTs actually reported any IR on doctoral education.

Secondly, Table 1 shows that IR reports on doctoral education are largely confidential and not readily available. It is thus difficult to determine the real nature and quality of such research. What further complicates the matter is that there were no clear indications of the dissemination of IR findings or the use of such findings by relevant institutional bodies or authorities. In at least three cases the respondents indicated that irrespective of the ways in which the results of projects were fed into institutional decision-making structures, they were unsure as to whether these recommendations were taken seriously or implemented. The problem of the observable or measurable impact of IR on doctoral education thus remains an issue, but also an issue in other domains of IR. 
Thirdly, the survey indicates that IR offices or units are only one role player in research on doctoral education. Other IR projects are conducted at, for instance, postgraduate offices, international offices, within faculties or schools and by individual academics who are interested in different aspects of doctoral education. Of the nine institutions that reported institutional research on doctoral education, at least five indicated that such research was conducted by units or individuals other than IR units. Useful institutional information on doctoral education is thus initiated and generated by a variety of institutional role players, which probably also points to the need for more coherent and coordinated ways of researching doctoral education at the institutional level.

Overall, the feedback and data on Southern African universities outside South Africa were disappointing. Apparently, most institutions focus on undergraduate rather than postgraduate education. Doctoral education, in particular, is not a focus. As the data in Table 2 are nonrepresentative and limited to only one institution and country, no particular findings can be considered. What it does show, however, is that there may be a serious lack of IR or reporting of IR on doctoral education in Southern African universities outside of South Africa.

\section{Conclusions on national and international research on doctoral education}

When the results of the limited survey are compared to national (South African) and international research on the topic, IR projects on doctoral education only partly account for the range and scope of such research. One would expect that international and national research agendas would inform IR projects more prominently as universities are part of national higher education systems, regional bodies and international scholarly communities. What we see, however, is that research topics such as doctoral throughput, efficiency and quality, supervision, equity and access, and the preparation of new academics are highlighted at the institutional level. At the national level the focus is on issues such as research on the nature of the doctorate, promoting careers of graduates outside of the academy, the funding of doctoral studies and the pipeline or feeding system of doctoral education. Research themes that rarely appear on local IR agendas include the study experiences of doctoral candidates, candidate diversity, internationalisation of the doctorate, women in doctoral research, the quality of doctoral examinations and writing as a key doctoral attribute.

One may thus conclude that, as IR on doctoral education appears to be limited within the South African and especially in the Southern African university context, the scope in terms of themes and topics when compared to national and international research agendas is also limited. This obviously provides for a more coherent and encompassing research role and agenda for IR on doctoral education, which is explored next.

\section{Roles and Agendas for Institutional Research on Doctoral Education}

\section{Roles for IR in research on doctoral education}

The current role of IR in research on doctoral education at many universities, worldwide and in South(ern) Africa, have been briefly discussed in preceding sections of this chapter. IR units and divisions provide important and useful data on their doctoral operations to institutional, regional or national information management systems and academic managers. 
Obviously such data are invaluable for planning, funding and quality assurance purposes; and the role of IR units in developing and disseminating such mechanisms has become increasingly sophisticated and useful - especially at the institutional level. There are, however, other roles to be played by IR in research on doctoral education which are not currently materializing, and which may be considered as being of potential future value to institutions and even beyond. At least three such roles may apply.

One IR role not currently evident is a coordinating role. From the international and South African data reported in this chapter, it is clear that both internationally and in South(ern) Africa, many IR projects on doctoral education are conducted by a spectrum of institutional role players. These include (post)graduate offices, international offices, graduate schools, independent research units, individual academics and doctoral candidates in higher education studies in faculties and departments. One implication is that all such potentially valuable information is 'scattered' within the institution and potentially lost for managerial and administrative use if not well coordinated.

A second IR role of potential value is to play a more prominent part in investigations into doctoral education for institutional competitive advantage. To monitor and capture doctoral enrolment trends, throughput figures, student diversity trends may be useful, but it tells us little about research needs in sectors that employ doctoral graduates, employment trends of doctoral graduates or the international mobility of an institution's doctoral graduates. These are issues of strategic importance that institutions and countries may well use to their advantage.

A third potentially useful role for IR on doctoral education is to initiate projects. Many institutional researchers outside of IR units embark on interesting and often useful research projects. Guidance by professional IR staff on how such projects could slot into larger research needs on doctoral education could result in using energy and resources more productively; in such cases IR units may need to initiate and announce research needs on doctoral education more prominently, and not merely in response to managerial requests. They could thus play a more initiating and advisory part in IR. The relative dearth of studies on doctoral education initiated and conducted by IR units may, however, be ascribed to the overriding demand for reporting that determines the agendas of these units, and to the concomitant lack of capacity to conduct more strategic research on a broader range of topics (see Chapter 4).

A final role with much potential for IR on doctoral education is information dissemination. As the results of the limited IR project survey showed, many project reports are either confidential or not properly disseminated and acted upon within institutions. While it is true that IR units are mainly in management support positions and not part of the line and decision-making function, disseminating information to the 'right' institutional constituents at the 'right' time and in the 'right' way may be valuable. One example would be better dissemination of information on the quality of doctoral examination procedures and reports which is one area of concern in South(ern) Africa in the light of an influx of doctoral candidates and projected increases in doctoral provision (also see Slabbert-Redpath 2015). 


\section{Agendas for IR in research on doctoral education}

Earlier in this chapter eleven prominent international themes of research on doctoral education were highlighted. Research conducted in South(ern) Africa was discussed, followed by the results taken from a limited survey of IR projects. Compared to international and regional project themes, there is clearly some ground to cover for IR at South(ern) African institutions. Future research agendas may thus include the following topics: longitudinal studies on doctoral education including studies that are able to pinpoint trends in external environments that include market needs for research graduates, the types of research education needed, doctoral employment patterns, doctoral migration patterns and the economic activities of doctoral graduates; projects focusing on quality measures in doctoral education, including projects on quality assurance data at the different stages of doctoral education and data on whether such quality measures are effective and efficient; the current excessive bureaucratisation of ethical clearance procedures may be one point of particular concern here, and such research would imply that the nature and aims of doctoral education are well understood by institutional researchers; the affordability of university studies and efficiency in the system have been under severe scrutiny lately and include doctoral studies and the ways in which doctoral education is facilitated and conducted, which provides a possible role for IR to indicate the ways in which doctoral studies could be made more affordable and use the different variants of doctoral education more efficiently to educate doctoral graduates at high levels of quality; the factors that inhibit Southern African universities to attract high quality academics as supervisors, along with building supervisory capacity for guiding future doctoral candidates, could also provide a particular focus; and finally, an increased focus on studies that involve both qualitative and mixed-methods data is needed, which implies a possible turn towards projects of a more scholarly nature and directed towards more meaningful, user-friendly and contextually sensitive data and findings.

- Longitudinal studies on doctoral education: This include studies that are able to pinpoint trends in external environments that include market needs for research graduates, the types of research education needed, doctoral employment patterns, doctoral migration patterns and the economic activities of doctoral graduates;

- Projects focusing on quality measures in doctoral education: Such projects may include quality assurance data at the different stages of doctoral education as well as data on whether such quality measures are effective and efficient. The current excessive bureaucratisation of ethical clearance procedures may be one point of particular concern. Such research would imply that the nature and aims of doctoral education are well understood by institutional researchers.

- In South(ern) Africa the affordability of university studies and efficiency in the system has been under severe scrutiny lately. This includes doctoral studies and how doctoral education is facilitated and conducted. A role for IR may be to indicate how doctoral studies could be made more affordable and how to use the different variants of doctoral education more efficiently to educate doctoral graduates efficiently at high levels of quality;

- A particular focus may also be on the factors that inhibit Southern African universities to attract high quality academics as supervisors and how to build supervisory capacity for guiding future doctoral candidates; 
- Finally, an increased focus on studies that involve both qualitative and mixed-methods data is needed. This implies a possible turn towards projects of a more scholarly nature and directed towards more meaningful, user-friendly and contextually sensitive data and findings.

\section{Conclusion}

What is clearly visible from the membership lists of the South African Association for Institutional Research (SAAIR) after the 21 years since its inception, is the underrepresentation of most Southern African universities outside South Africa. This limitation was also visible in the lack of IR project data on doctoral education. Moreover, too few IR projects on doctoral education at South African universities are apparently undertaken or reported, and, where they are reported, data and findings are not readily available or acted upon by relevant authorities. One may thus conclude with a reasonable measure of certainty that IR on doctoral education in Southern Africa still has a long way to reaching maturity. What emerged from this chapter is that internationally, and even nationally in South Africa, a number of important and valuable projects on doctoral education have been completed and reported. What may be needed is for IR on doctoral education at Southern African universities to adopt additional roles and agendas to flourish - including the tracking of candidates, the development of new user-friendly information systems and comparative work with other universities. In this way, SAAIR members may be in a better position to contribute substantially to IR on doctoral education for the next 21 years.

\section{References}

Acker S and E Hague. 2015. The struggle to make sense of doctoral study. Higher Education Research \& Development, 34(2): 229-241. http://dx.doi.org/10.108 0/07294360.2014.956699

Adkins B. 2009. PhD pedagogy and the changing knowledge landscapes of universities.

Higher Education Research \& Development, 28(2): 165-177. http://dx.doi. org/10.1080/07294360902725041

Aitchison C. 2015. Research Writing: purposes, practices and pedagogies in contemporary times. Keynote address at the 5th Biennial International Conference on Postgraduate Supervision. Spier, Stellenbosch. 24-27 March.

Aitchison C and S Mowbray. 2013. Doctoral women: managing emotions, managing doctoral studies. Teaching in Higher Education, 18(8): 859-870. http://dx.doi. org/10.1080/13562517.2013.827642

Altbach P and MJ Finkelstein. 2014. Forgetting the faculty. InsideHigherEd. https://www.insidehighered.com/ views/2014/10/07/essay-way-manyreformers-higher-education-areignoring-faculty-role [Retrieved on 20 December 2015].

Austin A and M McDaniels. 2006. Preparing the professoriate of the future: Graduate student socialization for faculty roles. In Smart JC (ed). Higher Education: Handbook of theory and research, 21: 397-456. The Hague: Springer.

Bansel P. 2011. Becoming academic: a reflection on doctoral candidacy. Studies in Higher Education, 36(5): 543-556. http://dx.doi.org/10.1080/03075079.20 11.594592

Bitzer EM and S Van den Bergh. 2014. Doctoral identity change towards researcher autonomy during research journeys across disciplines. South African Journal for Higher Education, 28(3): 1047-1068.

Boote DN and P Beile. 2005. Scholars before researchers: On the centrality of the dissertation literature review in research preparation. Educational 
Researcher, 34(6): 3 - 15. http://dx.doi. org/10.3102/0013189X034006003

Bourdieu, P. 1977. Outline of a theory of practice. Cambridge: Cambridge University Press. http://dx.doi. org/10.1017/CBO9780511812507

Boud D and M Tennant. 2006. Putting doctoral education to work: challenges to academic practice. Higher Education Research \& Development, 25(3): 293-306. http://dx.doi. org/10.1080/07294360600793093

Brown E. 2013. Why do we have more female scholars but fewer public intellectuals? https://bitchmedia.org/post/ why-do-we-have-more-female-scholarsbut-few-public-intellectuals [Retrieved on 20 December 2015].

Canal-Dominguez JF. 2014. Factors determining the career success of doctorate holders: evidence from the Spanish case. Studies in Higher Education, 39(10): 1750-1773. http:// dx.doi.org/10.1080/03075079.2013.80 6464

Cantwell R, S Bourke, J Scevak, A Holbrook and J Budd. 2015. Doctoral candidates as learners: A study of individual difference in responses to learning and its management. Studies in Higher Education. http://dx.doi.org/10.1080/030 75079.2015.1034263

Carter S. 2011. Doctorate as genre: supporting thesis writing across campus. Higher Education Research \& Development, 30(6): 725-736. http:// dx.doi.org/10.1080/07294360.2011.55 4388

Carter S, M Blumenstein and C Cook. 2013. Different for women? The challenges of doctoral studies. Teaching in Higher Education, 18(4): 339-351. http://dx.doi. org/10.1080/13562517.2012.719159

Chirikov I. 2013. Research universities as knowledge networks: the role of institutional research. Studies in Higher Education, 38(3): 456-469. http://dx.doi. org/10.1080/03075079.2013.773778

Cloete, N, J Mouton and C Sheppard (eds). 2015. Doctoral education in South Africa. Cape Town: African Minds.

Cotterall S. 2013. More than just a brain: emotions and the doctoral experience. Higher Education Research and
Development, 32(2): 174-178. http:// dx.doi.org/10.1080/07294360.2012.68 0017

Crede, E. and Borrego, M. 2014. Understanding retention in US graduate programs by student nationality. Studies in Higher Education, 39(9): 1599-1616. http://dx.doi.org/10.1080/03075079.20 13.801425

Cross, M. and Backhouse. J. 2014. Evaluating doctoral programmes in Africa: Context and practices. Higher Education Policy, 27: 155-174. http://dx.doi.org/10.1057/ hep. 2014.1

Du Preez, P. and Simmonds, S. 2015. Education research for quality PhD study curriculum- making: a South African meta-study. Preliminary unpublished research report to the National Research Foundation.

Emilsson, U.M. and Johnsson, E. 2007. Supervision of supervisors: on developing supervision in postgraduate education. Higher Education Research \& Development, 26(2): 163-179. http://dx.doi. org/10.1080/07294360701310797

Erichsen E.A., Bolliger, D.U. and Halupa, C. 2014. Student satisfaction with graduate supervision in doctoral programs primarily delivered in distance education settings. Studies in Higher Education, 39(2): 321-338. http://dx.doi.org/10.108 0/03075079.2012.709496

Ferrer de Valero, J. 2001. Departmental factors affecting time-to-degree and completion rates for doctoral students at one land-grant research institution. The Journal of Higher Education, 72(3): 341367. http://dx.doi.org/10.2307/2649335

Fillery-Travis, A.J. 2014. The framework of the generic DProf programme - a reflection on its design, the relational dimension for candidates and advisers and the potential for knowledge co-creation. Studies in Higher Education, 39(4): 608620. http://dx.doi.org/10.1080/0307507 9.2012.729031

Fox, M.F. 2001. Women, science, and academia. Graduate education and careers. Gender \& Society, 15(5): 654-666. http://dx.doi. org/10.1177/089124301015005002 
Frick, B.L. 2015. PhD by publication: An institutional analysis. Contributed paper at the 5th international conference on Postgraduate Supervision. Stellenbosch, Spier: 23-27 March.

Golde, C. 2005. The role of the department and discipline in doctoral student attrition: lessons from four departments. The Journal of Higher Education, 76(6): 669 - 700. http://dx.doi.org/10.1353/ jhe.2005.0039

Golde, C. and Dore, T.M. 2001. At cross purposes: What the experiences of today's doctoral students reveal about doctoral education. Research Report: University of Wisconsin.

Green, H. and Powell, S. 2005. Doctoral study in contemporary higher education. Buckingham: Open University Press.

Grove, J. 2013. Gender survey of the UK professoriate. The Times Higher Education. https://www. timeshighereducation.com/ news/gender-survey-of-ukprofessoriate-2013/2004766.article [Retrieved on 20 December 2015].

Habib, A., Price, M. and Mabelebele, J. 2014. Internationalisation; research and innovation in South Africa's universities. Presentation to the portfolio committee on Higher Education and Training. Cape Town: 3 September. http://pmg-assets. s3-website-eu-west-1.amazonaws. com/140903hesa.pdf [Retrieved on 20 December 2015].

Halse, C. 2011. 'Becoming a supervisor': the impact of doctoral supervision on supervisor's learning. Studies in Higher Education, 36(5): 557-570. http://dx.doi. org/10.1080/03075079.2011.594593

Halse, C. 2011a. Editorial: The impact of the doctorate. Studies in Higher Education, 36(5): 557-570. http://dx.doi.org/10.108 0/03075079.2011.594593

Halse, C. and Mowbray, S. 2011. The impact of the doctorate. Studies in Higher Education, 36(5): 513-525. http://dx.doi. org/10.1080/03075079.2011.594590

Hathaway R.S, Nagda, B.A. and Gregman, S.R. 2002. The relationship of undergraduate research participation to graduate and professional education pursuit: an empirical study. Journal of
College Student Development, 43(5): 1-18.

Herman, C. 2015. Looking back at doctoral education in South Africa. Studies in Higher Education. http://dx.doi.org/10.10 80/03075079.2015.1101756

HESA (Higher Education South Africa). 2011. Proposal for a National Programme to Develop the Next Generation of Academics for South Africa. Pretoria: HESA.

Hirshfield, L. and Joseph, T. 2012. 'We need a woman, we need a black woman': gender, race and identity taxation in the academy. Gender and Education, 24(2): 213-227. http://dx.doi.org/10.1080/095 40253.2011.606208

Holbrook, A., Shaw, K., Scevak, J., Bourke, S., Cantwell, R. and Budd, J. 2014. PhD candidate expectations: exploring mismatch with experience. International Journal of Doctoral Studies, 9: 329-346. http://dx.doi.org/10.1080/14703297.20 14.981842

Holbrook A., Bourke, S. and Fairbairn, $\mathrm{H}$. 2015. Examiner reference to theory in $\mathrm{PhD}$ theses. Innovations in Education and Teaching International, 52(1), 75-85. DO I:10.1080/14703297.2014.981842

Holbrook A., Bourke, S., Fairbairn, H. and Lovat, T. 2014. The focus and substance of formative comment provided by $\mathrm{PhD}$ examiners. Studies in Higher Education, 39(6): 983-1000. http://dx.doi.org/10.10 80/03075079.2012.750289

Hopwood, N. 2010. Doctoral students as journal editors: non-formal learning through academic work. Higher Education Research \& Development, 29(3): 319-331. http://dx.doi. org/10.1080/07294360903532032

Jørgensen, T.E. 2012. Codoc-cooperation on doctoral education between Africa, Asia, Latin America and Europe. Brussels: European University Association. Published report.

Kamler, B. and Thomson, P. 2014. Helping doctoral students write. Pedagogies for supervision. London: Routledge. Second Edition.

Kearns H., Gardiner, M, and Marshal, K. 2008. Innovation in $\mathrm{PhD}$ completion: the hardy shall succeed (and be happy!). Higher 
Education Research \& Development, 27(1): 77-89. http://dx.doi. org/10.1080/07294360701658781

Kiley, M. 2011. Developments in research supervisor training: causes and responses. Studies in Higher Education, 36(5): 585-599. http://dx.doi.org/10.108 0/03075079.2011.594595

Lee, A. 2008. How are doctoral student supervised? Concepts of doctoral research supervision. Studies in Higher Education, 33(3): 267-281. http://dx.doi. org/10.1080/03075070802049202

Lee, A., Brennan, M. and Green, B. 2009. Re-imagining doctoral education: Professional doctorates and beyond. Higher Education Research \& Development, 28(3): 275-287. http://dx.doi. org/10.1080/07294360902839883

Linden, J., Ohlin, M. and Brodin, E. 2013. Mentorship, supervision and learning experience in $\mathrm{PhD}$ education. Studies in Higher Education, 38(5): 639-662. http:// dx.doi.org/10.1080/03075079.2011.59 6526

Lovat, T., Holbrook, A. and Bourke, S. 2013. Ways of Knowing in doctoral examination. In M Murphy (Ed.) Social Theory and Education Research: Understanding Foucault, Habermas, Bourdieu and Derrida - A Four-Volume Set, Library of Educational Thought \& Practice Series. London: Sage.

Lovitts, B.E. 2005. How to grade a dissertation. Academe, NovemberDecember: 18-23.

Lovitts, B.E. 2008. Making the implicit explicit: creating performance expectations for the dissertation. San Francisco: Jossey-Bass.

Malfroy, J. 2011. The impact of universityindustry research on doctoral programs and practices. Studies in Higher Education, 36(5); 571-584. http://dx.doi. org/10.1080/03075079.2011.594594

Mason, M.A. 2014. The pyramid problem. The Chronicle of Higher Education. http://chronicle.com/article/ThePyramid-Problem/126614 [Retrieved on 20 December 2015].

Maton, K. 2012. 'Habitus', in Grenfell, M. (ed): Pierre Bourdieu: Key concepts. London: Acumen Press. Pp. 48
- 64. http://dx.doi.org/10.1017/

UPO9781844654031.006

Maxwell, T.W. and Smyth, R. 2011. Higher degree research supervision: from practice toward theory. Higher Education Research \& Development, 30(2): 219231. http://dx.doi.org/10.1080/0729436 0.2010 .509762

McAlpine, L. and Norton, J. 2006. Reframing our approach to doctoral programs: an integrative framework for action and research. Higher Education Research \& Development, 25(1): 3 - 17. http://dx.doi. org/10.1080/07294360500453012

McAlpine L., Jazvac-Martek, M. and Hopwood, N. 2009. Doctoral student experience in education: Activities and difficulties influencing identity development. International Journal for Researcher Development, 1(1): 97-109. http://dx.doi. org/10.1108/1759751X201100007

McCallin, A. and Nayar, S. 2011. Postgraduate research supervision: a critical review of current practice. Teaching in Higher Education, 17(1): 6374. http://dx.doi.org/10.1080/13562517 .2011 .590979

Mewburn, I. 2011. Troubling talk: assembling the $\mathrm{PhD}$ candidate. Studies in Continuing Education, 33(3): 321-332. http://dx.doi. org/10.1080/0158037X.2011.585151

Mouton, J. 2007. Postgraduate studies in South Africa: Myths, misconceptions and challenges. South African Journal for Higher Education, 21(8): 1078-1090.

Mouton, J. 2015. The doctorate in South Africa: current debates and future challenges. Keynote address at the 5th Biennial International Conference on Postgraduate Supervision. Spier, Stellenbosch. 24-27 March.

Mowbray, S. and Halse, C. 2010. The purpose of the PhD: theorising the skills acquired by students. Higher Education Research \& Development, 29(6): 653664. http://dx.doi.org/10.1080/0729436 0.2010 .487199

Neumann, R. 2003. The doctoral education experience: Diversity and complexity. Australian Government, Department of Education, Science and Training. Canberra. http://www.dest. gov.au/ 
NR/rdonlyres/873B3698-F3BA-4D86869C-0C3C6DB95658/804/03_12.pdf (accessed September 26, 2015).

Neumann, D. 2007. Policy and practice in doctoral education. Studies in Higher Education, 32 (4): 459-473. http://dx.doi. org/10.1080/03075070701476134

Neumann, R. and Tan, KK. 2011. From PhD to initial employment: the doctorate in a knowledge economy. Studies in Higher Education, 36(5): 601-514. http://dx.doi. org/10.1080/03075079.2011.594596

Park, C. 2005. New variant PhD: The changing nature of the doctorate in the UK. Journal of Higher Education Policy and Management, 27(2): 189-207. http://dx.doi. org/10.1080/13600800500120068

Park, C. 2007. Redefining the doctorate. York: Higher Education Academy.

Pearson, M. and Brew, A. 2002. Research training and supervision development. Studies in Higher Education, 27(2): 135-150. http://dx.doi. org/10.1080/03075070220119986c

Pearson M., Cumming J., Evans, T., Macauley, P. and K Ryland. 2011. How shall we know them? Capturing the diversity of difference in Australian doctoral candidates and their experiences. Studies in Higher Education, 36(5): 527-542. http://dx.doi.org/10.1080/03075079.20 11.594591

Poole, B. 2014. The rather elusive concept of 'doctorateness': a reaction to Wellington. Studies in Higher Education. http:// dx.doi.org/10.1080/03075079.2013.87 3026

Powell, S. and Green, H. 2007. The doctorate worldwide. Buckingham: Open University Press.

Prinsloo, P. 2014. Mene mene tekel upharsin: researcher identity and performance. University of South Africa: Inaugural lecture, 22 October.

Salter, D.W. 2013. One university's approach to defining and supporting professional doctorates. Studies in Higher Education, 38(8): 1175-1184. http://dx.doi.org/10.1 080/03075079.2013.833030

Schömburg, H. and Teichler, U. 2006. Higher education and graduate employment in Europe. Results from graduate surveys from twelve countries. Dordrecht: Springer.

Scott, D.L. 2012. How higher education in the US was destroyed in 5 basic steps. Alternet. http://www.alternet.org/howhigher-education-us-was-destroyed-5basic-steps [Retrieved on 20 December 2015].

Shreeve, A. 2010. Joining the dots: the scholarship of teaching as part of institutional research. Higher Education Research \& Development, 30(1): 36-74.

Sinclair, J., Barnacle, R. and Cuthbert, D. 2014. Hoe the doctorate contributes to the formation of active researchers; what the research tells us. Studies in Higher Education, 39(10): 1972- 1986. http:// dx.doi.org/10.1080/03075079.2013.80 6460

Slabbert-Redpath, J. 2015. A critical perspective of quality assurance in the examination of doctoral theses in education sciences at South African universities. Unpublished draft PhD script.

Starfield, S., Paltridge, B., McMurtrie, R., Holbrook, A., Bourke, S., Fairbairn, H., Kiley, M. and Lovat, T. 2015. Understanding the language of evaluation in examiners' reports on doctoral theses. Linguistics and Education 31:130-144. http://dx.doi.org/10.1016/j. linged.2015.06.004

Stubb J., Pyhato, K. and Lonka, K. 2014. Conceptions of research: the doctoral student experience in three domains. Studies in Higher Education, 39(2):251264. http://dx.doi.org/10.1080/0307507 9.2011.651449

Taylor, S. and Beasley, N. 2005. A handbook for doctoral supervisors. London: Routledge Falmer. http://dx.doi. org/10.4324/9780203415740

The Presidency. 2011. National Development Plan - Vision for 2030. Pretoria: National Planning Commission. South Africa.

Tight, M. 2012. Researching higher education. Maidenhead: Open University Press. Second Edition.

Trafford, V. 2012. Presentation on doctorateness at a workshop of the Centre for Higher and Adult Education, Stellenbosch University. 28 - 29 January. 
Trafford, V. and Leshem, S. 2009. Doctorateness as a threshold concept. Innovations in Education and Teaching International, 46(3): 305-316. http://dx.doi. org/10.1080/14703290903069027

Trafford, V. and Leshem, S. 2011. Stepping stones to achieving your doctorate. Maidenhead: Open University Press. 2nd Imprint.

Trafford, V., Leshem, S. and Bitzer, E.M. 2014. Conclusion chapters in doctoral theses: some international findings. Higher Education Review, 46(3): 52-81.

Kotecha, P. (ed.). 2012. Internationalisation in Higher Education. Perspectives from the Global South. Sarua Leadership Dialogue Series 4 (2).

United Kingdom Council for Graduate Education. 2012. Professional doctorates. Litchfield: UKCGE.

Usher, R. 2002. A diversity of doctorates: Fitness for the knowledge economy? Higher Education Research \& Development, 21(2): 143-153. http://dx.doi. org/10.1080/07294360220144060

Van der Haert, M., Arias, O.E., Empli, P., Hallion, V. and Dehon. C. 2014. Are dropout and degree completion in doctoral study significantly dependent on type of financial support and field of research? Studies in Higher Education, 39(10); 1885-1909. http://dx.doi.org/10. 1080/03075079.2013.806458

Van der Merwe, J. 2014. Where are our black academics? City Press. http://city-press. news24.com/black-academics [Retrieved 20 December 2015]

Walker, G.E., Golde, C.M., Jones, L., ConklinBueschel, A. and Hutchings, P. 2008. The formation of scholars. Rethinking doctoral education for the Twenty-first Century. San Francisco, CA: Jossey-Bass.

Wallingham. 1974. Predicting success in graduate education. Science, 183, 4122: 273-278.

Webber, K.L. and Calderon, A.J. 2015. Institutional research and planning: Its role in higher education decision support and policy development. The Palgrave International Handbook of Higher Education Policy and Governance. New York: Routledge.

Wellington, J. 2013. Searching for 'doctorateness'. Studies in Higher Education, 38(10):1490-1503. http:// dx.doi.org/10.1080/03075079.2011.63 4901

Wildly, H., Peden, S. and Chan, K. 2015. The rise of professional doctorates: case studies of the doctorate in Education in China, Iceland and Australia. Studies in Higher Education, 40(5):761-774. http:// dx.doi.org/10.1080/03075079.2013.84 2968

Willison, J.W. and O'Regan, K. 2007. Commonly known, commonly not known, totally unknown: A framework for students becoming researchers. Higher Education Research and Development 26(4):393-409. http://dx.doi. org/10.1080/07294360701658609 